\title{
Parental Involvement in Education Among Albanian Parents
}

\author{
Voltisa Thartori \\ Kulliyyah of Education, \\ International Islamic University Malaysia \\ Kuala Lumpur \\ voltisat@gmail.com
}

\begin{abstract}
Parents' involvement has a huge influence on children's educational engagement and achievement during the elementary years. With this idea forming its backbone, the study examined the extent to which Albanian parents took active part in their children's education at a selected elementary school in Albania. The parental involvement construct examined in the study was conceptualized based on Epstein's (1995) six categories of involvement: parenting, communicating, volunteering, learning at home, decision-making, and collaborating with the community. Epstein's survey instrument was used to collect data from 80 parents. Data were analyzed with descriptive statistics, Pearson correlation and ANOVA. The results showed a high level of parental involvement among the respondents, particularly in terms of support towards school programs and student activities. Volunteerism was high among the respondents where they reported helping out with many workshops conducted by the school. Some parents maintained good communication with the school and teachers, and were not hesitant to consult the teachers whenever the need arose. The ANOVA results showed statistically significant differences in parental involvement by age, marital status, education level, and income level. Of the six components, parenting, communicating, and volunteering were identified as the most important aspects of parental involvement.
\end{abstract}

Keywords: Parental involvement, parenting, communicating, volunteering, learning at home, decision-making, collaborating with the community, Albanian parents.

\section{INTRODUCTION}

In the education of children, two main agents that play a fundamental role are the school and the family. The family shapes the minds of children through informal education, while the school provides children with formal schooling. These two forms of education cumulatively make up children's foundational learning (Edwards, 2002). However, many parents are not aware of the crucial role they play in children's academic success, holding schools completely responsible for the good or bad performance of their children. Scores of parents tend to believe that children should be educated by those who are more suited to the tasks of teaching, training, and educating, i.e. teachers. In this mindset, they perceive the school to be solely responsible for the education of their children. Hence, schools are often left alone to act as the sole teaching agent (Bloom, 1997) with little parental involvement, if any.

A good amount of research has indicated the influence and importance of parental involvement in school with the understanding that parent-school collaboration is an important ingredient for children's educational success. Hence, by knowing the importance of parental 
involvement, parents can help their children to derive maximum benefits from schooling. Thus, parents should take an active part in their children's education with careful thought and consideration, and not do so carelessly. Parents' involvement in this process should bring about a positive and significant influence on the academic success and holistic development of children (Rosenberg \& Lopez, 2010).

Lee and Bowen (2006) define parental involvement as participating in parent-teacher conferences in which parents and teachers discuss children's homework and experiences at school as well as structuring educational and learning activities at home. It includes both behaviors at home as well as at school. Research defines parental involvement by the area where the involvement of parents takes place, differentiating among home-based involvement, school-based involvement, and home-school communication (Barnard, 2004; Manz et al., 2004). Epstein (1995) define parental involvement as families and communities taking an active role in creating a caring educational environment for children.

Research has identified several factors to be contributing to this caring environment. Moore (1991), for instance, recognized parents as volunteers and helpers of children's development. His idea of parents as school volunteers and helpers constitutes one aspect of parental involvement. Apart from Moore (1991), Flaxman and Inger (1992) proposed other ways in which parents can get involved in their children's schooling, such as by being part of the school organization and decision making, participating in unique and special parenting programmes organized by the school, and providing full support to the said programmes. A prominent parental involvement scholar, Epstein (1995), identified six types of parental involvement. They comprise parenting, communicating, volunteering, learning at home, decision-making, and collaborating with the community.

\section{LITERATURE REVIEW}

Understanding parental involvement in children's education will certainly help educators to comprehend the factors that influence the weakness and strength of the relationship among the school, teachers and parents. Consequently, this understanding will help increase parents' involvement in schooling and make it more effective.

\section{Defining Parental Involvement}

Research on parent involvement in children's education is not unanimously positive. However, it has been found that parents and educators define involvement differently. That is, parents take a more community-centric view which focuses on keeping their children safe and getting them to school, whereas teachers define involvement primarily as parental presence at school. Because parents and educators define involvement differently, problems such as miscommunication can occur that lead teachers to blame families for child difficulties and parents to feel unappreciated for their efforts (Lawson, 2003, as cited in Anderson \& Minke, 2007). It is also difficult for families to comply with teachers' expectations because of varying levels of resources. For instance, work schedules of middle-class families are more flexible and they have easier access to transportation than do working-class families, making it easier for them to be present at school and to receive acknowledgments (Lareau, 1989; as cited in Anderson \& Minke, 2007). We need to understand parents' involvement options, taking into consideration that lower resource families may respond differently than do families with greater 
resources. In addition to that, parent involvement must include home based elements as well as school based elements.

In Anderson and Minke (2007), parents regard their involvement in their children's education as a positive factor in academic learning and academic success. The researchers discovered that parents and teachers tend to define parental involvement differently. While parents tend to take a community-centric view that focuses on keeping their children safe and getting them to school, teachers tend to view involvement as parental presence at school. While parents wish to have more involvement in education at home than at school, teachers want to see more of parents at school (Anderson \& Minke, 2007).

Lee and Bowen (2006) utilize a typology that takes into consideration both the activities and areas of parental involvement. The typology measures (i) parent involvement in school; (ii) parent-child educational discussion; (iii) homework help; (iv) time management; and (v) parent educational expectations. There is a huge variation among researchers and scholars regarding what the construct means, resulting in a lack of cohesion in its conceptualization and terminology (Christenson \& Hurley, 1997; McCarthey, 2000). For example, the terms "parent involvement," "family involvement," "parent engagement," "parent empowerment," and "school-family partnerships" are often used interchangeably to mean parents' taking an active part. Thus in this study, the term "parental involvement" was taken to mean all activities parents engaged in to help their children succeed in school.

Of great importance to the parental involvement literature was the work of Joyce Epstein who has extensively examined the construct and its effects on the educational process. Epstein identified six major types of parental involvement, namely parenting, communicating, volunteering, learning at home, decision making, and collaborating with the community (Epstein et al., 2009). These six dimensions have helped researchers to understand the nature of involvement in a more coherent and meaningful way.

\section{Impact of Parental Involvement}

Studies spawning three decades have shown that parental involvement is very important in the learning process of children, in their opinion about school, and their aspirations. Children are more successful students throughout their schooling if their parents participate in their school learning and encourage learning at home, regardless of education or social level (Epstein, 2001). Hashmi and Akhter (2013) examined the impact of parental involvement on 600 Pakistani students' academic success, and found high levels of involvement to result in high achievement scores among the respondents. Similarly, Deplanty, Coulter, Kern, and Duchane (2007) found parental involvement to be a crucial factor for the academic success of the learners. In fact, research has established that parent involvement in children's learning at home is more instrumental to children's academic success than involvement in the school setting. As parents are their children's first and foremost teachers and play a paramount role in helping them succeed in school, parents need to become involved very early on and stay involved throughout the elementary school period.

Parent involvement impacts a child's level of commitment during the fundamental years of schooling. Plenty of research has highlighted that parent involvement is a substantial factor that affects students' academic success and performance. Parents influence children's intellectual, social and emotional development, and inspire their educational commitment as well as professional ambitions (Rosenberg \& Lopez, 2010). 


\section{Parent Demographics and Parental Involvement}

Parent involvement differs on numerous aspects such as education level, socioeconomic status, and marital status. These are several significant features influencing their involvement in children's schooling. Parents' expectations about their children's academic performance are related to socio-economic status (Lee \& Bowen, 2006), thereby influencing the degree to which they are involved in the academic matters of their kids. Anderson and Minke (2007) examined the relationship among four parent-related variables, namely role construction, sense of efficacy, resources, and perceptions of teacher invitations, and found that parental involvement activities at home and engagement in the early years of schooling promoted not only a child's motivation, self-efficacy, and social behavior, but also his/her reading and mathematical skills.

Parents' education level is a crucial component in stimulating children's interest in academic learning and progress (Wigfield, Eccles, Schiefele, Roeser \& Davis-Kean, 2006). Highly educated parents tend to have a positive impact on children's learning and motivation because of their ability to make learning enjoyable for their children. Baroody and Dobbs-Oates (2009) supported this observation, finding that parents' education level was related to achievement motivation among elementary school students in both direct and indirect ways. Hence, children of highly educated parents are likely to become more interested in academic learning than those of less educated ones. In a longitudinal study on the role of parental involvement in academic success involving 463 U.S. adolescents, Hill et al. (2004) discovered that parents' education level and socioeconomic status significantly influenced their involvement in the academic learning, progress and success of their children. Hence, parental involvement in the education of students begins at home with parents providing a safe and healthy environment; appropriate learning experiences, support, and a positive attitude towards school.

Vellymalay (2012) examined the relationship between parents' socioeconomic status and involvement in their children's education at home. The findings showed that mothers were more involved than fathers in their children's education and in helping them in academic learning. Therefore, it can be reasonably assumed that mothers tend to feel that they have a greater responsibility in helping their children academically than do fathers.

\section{Statement of the Problem}

The need to succeed in school has placed an increasing demand on modern day parents to participate fully and meaningfully in the education of their children. Although parental involvement in children's education is paramount, parents of today have minimal time and limited ability to make this involvement happen due to their tight working schedules and other responsibilities (Swap, 1993). Much empirical work has looked into this phenomenon, but there is still a need to address the nature and components that elucidate this involvement. In other words, what exactly constitutes effective parental involvement in children's education? Thus far, schools have defined the concept of parental involvement with little or no input from parents. Although these definitions can easily be found in research, they lack the variety of involvement practices exhibited by parents in real life (Jordan, Orozco, \& Averett, 2002).

Demographic factors, such as socioeconomic status, marital status and educational level, are likely to influence the nature of parental involvement. Some research has indicated a relationship between parent demographics and parental involvement in children's education. However, research examining the relationship between parent demographics and their involvement in children's schooling in Albania is lacking. In an attempt to fill this gap, this 
research examined the level of Albanian parents' school involvement, whether this involvement varied by demographic characteristics (e.g. income level, marital status, education level, and age), and the relationship between two of Epstein's parental involvement categories (parenting and communicating).

\section{Research Objectives and Questions}

Generally, this study explored Albanian parents' involvement in their children's schooling at a public school in Albania, and examined whether demographic factors (i.e. age, marital status, educational level, and income level) significantly characterized their involvement. Additionally, the study looked at the relationship between parenting and communicating, which are two components of Epstein's parental involvement framework. In connection to the objectives, three research questions were asked:

1. What is the extent of Albanian parents' involvement in their children's education?

2. Does their involvement differ by demographic factors (i.e. age, marital status, educational level and income level)?

3. What is the relationship between parenting and communication, i.e. the two categories of parental involvement examined in the study?

\section{METHODS}

\section{Research Design}

The study employed the ex-post facto, cross-sectional survey design. Ex-post facto means after the fact or "from what is done afterwards" (Simon \& Goes, 2013, p. 2). It is categorized as expost facto because no experimental manipulation was exerted by the researcher on the phenomenon being examined, i.e. Albanian parents' involvement in their children's education and schooling, meaning that prior to data collection, this involvement already occurred. It is a cross-sectional study because it involved looking at a sample of Albanian parents whose parental involvement might differ according to some key features like age, marital status, educational level and income level, hence creating different sections of the sample.

\section{Population and Sample}

The ideal population consisted of all Albanian parents who registered their children at the selected public school located in Fushe Kruje, Albania during the 2015-2016 academic years. The total number was approximated at 1,000 parents. The study's target population comprised the parents of Grades 1 to 5 pupils registered at the school.

The sample was a convenience sample of 80 Albanian parents who responded to the survey voluntarily. The survey was administered to 120 parents, and from this number, 100 returned the questionnaire. However, only 80 cases were usable as 20 parents did not fill up the demographic section of the questionnaire. The profile of the 80 parents who did respond is provided in Table 1. 
Table 1

The Respondents' Demographic Profile $(\mathrm{N}=80)$

\begin{tabular}{|c|c|c|}
\hline Demography & Frequency $(\mathrm{N})$ & Percentage $(\%)$ \\
\hline $\begin{array}{ll}\text { Marital Status } \\
\text { - } & \text { Married } \\
\text { - } & \text { Divorced/Separated } \\
\text { - } & \text { Widowed } \\
\text { - } & \text { Never married }\end{array}$ & $\begin{array}{c}58 \\
11 \\
4 \\
7\end{array}$ & $\begin{array}{c}72.5 \\
13.8 \\
5.0 \\
8.8\end{array}$ \\
\hline $\begin{aligned} \text { Relationship with Child } \\
\text { - } \\
\text { - } \text { Fother } \\
\text { - } \text { Stepmor } \\
\text { - Stepfather }\end{aligned}$ & $\begin{array}{c}51 \\
19 \\
8 \\
2\end{array}$ & $\begin{array}{c}63.8 \\
23.8 \\
10.0 \\
2.5\end{array}$ \\
\hline $\begin{array}{ll}\text { Age Group } \\
. \quad 18-19 \\
. \quad 20-29 \\
=\quad 30-39 \\
. \quad 40-49 \\
=\quad 50 \text { and more }\end{array}$ & $\begin{array}{c}2 \\
18 \\
23 \\
28 \\
9\end{array}$ & $\begin{array}{c}2.5 \\
22.5 \\
28.8 \\
35.0 \\
11.3\end{array}$ \\
\hline $\begin{array}{l}\text { Education Level } \\
\text { - } \text { Less than high school } \\
\text { - } \text { High school } \\
\text { - Bacheloge } \\
\text { - Graduate degree }\end{array}$ & $\begin{array}{c}11 \\
21 \\
34 \\
5 \\
9\end{array}$ & $\begin{array}{c}13.8 \\
26.3 \\
42.5 \\
6.3 \\
11.3\end{array}$ \\
\hline 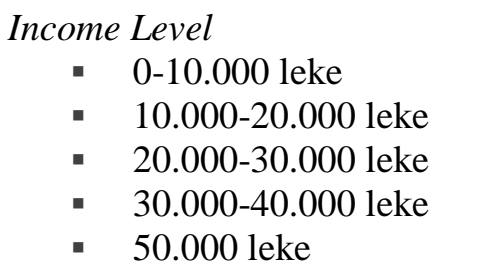 & $\begin{array}{l}31 \\
18 \\
17 \\
8 \\
6\end{array}$ & $\begin{array}{l}38.8 \\
22.5 \\
21.3 \\
10.0 \\
7.5\end{array}$ \\
\hline
\end{tabular}

A majority of the sample were mothers and stepmothers (74\%), married (73\%), aged between 20 and 49 (86\%), and were high school $(26.3 \%)$ and college $(43 \%)$ educated. Fathers and stepfathers made up $34 \%$ of the sample. Most of the respondents were low-income families with a monthly earning of 30,000 leke or less $(83 \%)$. Only $17.5 \%$ were high income parents earning 30,000 leke or more per month.

\section{Instrument}

The instrument was a parental involvement questionnaire adapted from Epstein et al. (2009). It asked twenty-nine (29) questions on six dimensions of involvement (i.e. parenting, communication, volunteering, learning at home, decision making, and collaborating with the community) on a 5-point frequency scale consisting of Never (1), Rarely (2), Sometimes (3), Frequently (4), and Always (5). 


\section{DATA ANALYSIS}

The data were coded and entered into SPSS and analyzed using descriptive statistics and ANOVA. ANOVA was employed to examine differences in parental involvement by age, education level, income level, and marital status. Post hoc analyses using the Tukey test were then used to determine where the exact differences lay (McMillan \& Schumacher, 2006).

\section{Extent of Parental Involvement among Albanian Parents}

\section{Parenting}

Table 2 shows the extent of involvement in the aspect of parenting. The data indicate the frequencies at which the Albanian parents responded to the school's calls for active parenting. A majority indicated that they frequently and always attended workshops for parents conducted by the school $(57.6 \%)$, provided information to the school about their children's learning when requested $(61.4 \%)$, were clear about their children's learning goals $(66.4 \%)$, welcomed home visits by the school (63.8\%), and provided conducive learning environments at home $(64 \%)$.

Table 2

Albanian Parents' Involvement in Parenting ( $\mathrm{N}=80)$

\begin{tabular}{lccccc}
\hline \multirow{2}{*}{ Parenting Items } & \multicolumn{5}{c}{ Frequency } \\
\cline { 2 - 6 } & Never & Rarely & Sometimes & Frequently & Always \\
\hline $\begin{array}{l}\text { Attending workshops conducted } \\
\text { by the school }\end{array}$ & 0 & 17 & 17 & 30 & 16 \\
$\begin{array}{l}\text { Providing information about } \\
\text { children's learning }\end{array}$ & 0 & $(21.3 \%)$ & $(21.3 \%)$ & $(37.6 \%)$ & $(20.0 \%)$ \\
$\begin{array}{l}\text { Being clear about children's } \\
\text { learning goals }\end{array}$ & 0 & 5 & 26 & 23 & 26 \\
$\begin{array}{l}\text { Welcoming visits to home by the } \\
\text { school }\end{array}$ & $(0)$ & $(7.6 \%)$ & $(26.3 \%)$ & $(38.8 \%)$ & $(27.6 \%)$ \\
$\begin{array}{l}\text { Providing good conditions that } \\
\text { support learning }\end{array}$ & $(1.3 \%)$ & $(11.3 \%)$ & $(25.0 \%)$ & $(35.0 \%)$ & $(28.8 \%)$ \\
& $(1.3 \%)$ & $(7.6 \%)$ & $(27.6 \%)$ & $(41.3 \%)$ & $(22.6 \%)$ \\
\hline
\end{tabular}

\section{Communication}

Table 3 presents the distribution of the parents' responses to eight items concerning communication with the school about their children's education and schooling.

Table 3

Albanian Parents' Involvement in Communication ( $\mathrm{N}=80)$

\begin{tabular}{lccccc}
\hline \multirow{2}{*}{ Parenting Item } & \multicolumn{5}{c}{ Frequency } \\
\cline { 2 - 6 } & Never & Rarely & Sometimes & Frequently & Always \\
\hline $\begin{array}{l}\text { Communicating with parents } \\
\text { who don't speak English }\end{array}$ & 16 & 23 & 32 & 8 & 1 \\
$\begin{array}{l}\text { Establishing a two-way } \\
\text { communication between }\end{array}$ & 1 & $(28 \%)$ & $(40 \%)$ & $(10 . \%)$ & $(1.3 \%)$ \\
home and school & $(1.3 \%)$ & $(13.8 \%)$ & $(32.6 \%)$ & $(36.3 \%)$ & $(16.3 \%)$ \\
$\begin{array}{l}\text { Attending the school's } \\
\text { teacher-parent conferences }\end{array}$ & 0 & & & & \\
& $(0)$ & $(6.3 \%)$ & $(25 \%)$ & $(40 \%)$ & $(28.8 \%)$
\end{tabular}




\begin{tabular}{|c|c|c|c|c|c|}
\hline $\begin{array}{l}\text { Participating in the school's } \\
\text { annual survey }\end{array}$ & $\begin{array}{c}1 \\
(1.3 \%)\end{array}$ & $\begin{array}{c}6 \\
(7.5 \%)\end{array}$ & $\begin{array}{c}19 \\
(23.8 \%)\end{array}$ & $\begin{array}{c}33 \\
(41.3 \%)\end{array}$ & $\begin{array}{c}21 \\
(26.3 \%)\end{array}$ \\
\hline $\begin{array}{l}\text { Attending orientation for } \\
\text { new parents }\end{array}$ & $\begin{array}{c}14 \\
(17.5 \%)\end{array}$ & $\begin{array}{c}13 \\
(16.3 \%)\end{array}$ & $\begin{array}{c}16 \\
(20 . \%)\end{array}$ & $\begin{array}{c}24 \\
(30 \%)\end{array}$ & $\begin{array}{c}13 \\
(16.3 \%)\end{array}$ \\
\hline $\begin{array}{l}\text { Checking child's planner/ } \\
\text { folder }\end{array}$ & $\begin{array}{c}13 \\
(16.3 \%)\end{array}$ & $\begin{array}{c}21 \\
(26.3 \%)\end{array}$ & $\begin{array}{c}29 \\
(36.3 \%)\end{array}$ & $\begin{array}{c}11 \\
(13.8 \%)\end{array}$ & $\begin{array}{c}6 \\
(6.5 \%)\end{array}$ \\
\hline $\begin{array}{l}\text { Being aware of } \\
\text { child's/children's academic or } \\
\text { behavior problems }\end{array}$ & $\begin{array}{c}0 \\
(0)\end{array}$ & $\begin{array}{c}9 \\
(11.3 \%)\end{array}$ & $\begin{array}{c}23 \\
(28.8 \%)\end{array}$ & $\begin{array}{c}30 \\
(37.5 \%)\end{array}$ & $\begin{array}{c}18 \\
(22.5 \%)\end{array}$ \\
\hline $\begin{array}{l}\text { Communicating regularly } \\
\text { with school }\end{array}$ & $\begin{array}{c}0 \\
(0)\end{array}$ & $\begin{array}{c}9 \\
(11.3 \%)\end{array}$ & $\begin{array}{c}21 \\
(26.3 \%)\end{array}$ & $\begin{array}{c}35 \\
(43.8 \%)\end{array}$ & $\begin{array}{c}15 \\
(18 \%)\end{array}$ \\
\hline
\end{tabular}

In terms of contact and communication with the school, most parents frequently attended teacher-parent conferences (69\%), responded to the school's annual survey (68\%), communicated regularly $(62 \%)$ and had a two-way communication with the school $(53 \%)$. Sixty percent $(60 \%)$ were reportedly aware of their child's/children's academic and behaviour problems. However, few frequently checked their child's/children's academic files $(20 \%)$ or communicated with parents who do not speak English (11\%).

\section{Volunteering}

Table 4 shows the respondents' involvement in terms of volunteering at their children's school. The items in this category show the types of help parents extended to the school.

Table 4

Albanian Parents' Involvement in Volunteering $(\mathrm{N}=80)$

\begin{tabular}{|c|c|c|c|c|c|}
\hline \multirow{2}{*}{ Parenting Item } & \multicolumn{5}{|c|}{ Frequency } \\
\hline & Never & Rarely & Sometimes & Frequently & Always \\
\hline $\begin{array}{l}\text { Helping school } \\
\text { with annual survey }\end{array}$ & $\begin{array}{l}0 \\
(0)\end{array}$ & $\begin{array}{l}3 \\
(3.8 \%)\end{array}$ & $\begin{array}{l}24 \\
(30 \%)\end{array}$ & $\begin{array}{l}34 \\
(42.5 \%)\end{array}$ & $\begin{array}{l}19 \\
(23.8 \%)\end{array}$ \\
\hline $\begin{array}{l}\text { Helping school to } \\
\text { cater to the needs } \\
\text { of other parents }\end{array}$ & $\begin{array}{l}0 \\
(0)\end{array}$ & $\begin{array}{l}9 \\
(11.3 \%)\end{array}$ & $\begin{array}{l}20 \\
(25.5 \%)\end{array}$ & $\begin{array}{l}33 \\
(41.3 \%)\end{array}$ & $\begin{array}{l}18 \\
(22.5 \%)\end{array}$ \\
\hline $\begin{array}{l}\text { Helping school } \\
\text { with special events }\end{array}$ & $\begin{array}{l}0 \\
(0)\end{array}$ & $\begin{array}{l}7 \\
(8.8 \%)\end{array}$ & $\begin{array}{l}23 \\
(28.8 \%)\end{array}$ & $\begin{array}{l}29 \\
(36.3 \%)\end{array}$ & $\begin{array}{l}21 \\
(26.3 \%)\end{array}$ \\
\hline $\begin{array}{l}\text { Helping school to } \\
\text { show appreciation } \\
\text { for volunteers }\end{array}$ & $\begin{array}{l}0 \\
(0)\end{array}$ & $\begin{array}{l}11 \\
(13.8 \%)\end{array}$ & $\begin{array}{l}18 \\
(22.5 \%)\end{array}$ & $\begin{array}{l}31 \\
(38.8 \%)\end{array}$ & $\begin{array}{l}20 \\
(25 \%)\end{array}$ \\
\hline
\end{tabular}

The results indicate widespread volunteerism among the parents. Most had extended help to the school in many ways, for example with the annual school survey $(66 \%)$ and special events $(63 \%)$ and by catering to the needs of other parents/families (64\%). Very few reported never or rarely helping out in these aspects, i.e., between $3.8 \%$ and $13.8 \%$. 


\section{Learning at Home}

Table 5 shows the respondents' involvement in terms of helping their children to learn at home. The items in this category show the types of support parents extended to their child/children in terms of studying, homework and giving feedback.

Table 5

Albanian Parents' Involvement in Learning at Home $(\mathrm{N}=80)$

\begin{tabular}{|c|c|c|c|c|c|}
\hline \multirow{2}{*}{ Parenting Item } & \multicolumn{5}{|c|}{ Frequency } \\
\hline & Never & Rarely & Sometimes & Frequently & Always \\
\hline $\begin{array}{l}\text { Guiding child/children } \\
\text { in studying }\end{array}$ & $\begin{array}{c}0 \\
(0)\end{array}$ & $\begin{array}{c}7 \\
(8.8 \%)\end{array}$ & $\begin{array}{c}24 \\
(30 \%)\end{array}$ & $\begin{array}{c}27 \\
(33.8 \%)\end{array}$ & $\begin{array}{c}22 \\
(27.5 \%)\end{array}$ \\
\hline $\begin{array}{l}\text { Reading to child/ } \\
\text { children }\end{array}$ & $\begin{array}{c}1 \\
(1.3)\end{array}$ & $\begin{array}{c}6 \\
(7.5 \%)\end{array}$ & $\begin{array}{c}23 \\
(28.8 \%)\end{array}$ & $\begin{array}{c}27 \\
(33.8 \%)\end{array}$ & $\begin{array}{c}23 \\
(28.8 \%)\end{array}$ \\
\hline $\begin{array}{l}\text { Helping child/children } \\
\text { with homework }\end{array}$ & $\begin{array}{c}1 \\
(1.3)\end{array}$ & $\begin{array}{c}8 \\
(10 \%)\end{array}$ & $\begin{array}{c}25 \\
(31.3 \%)\end{array}$ & $\begin{array}{c}21 \\
(26.3 \%)\end{array}$ & $\begin{array}{c}25 \\
(31.3 \%)\end{array}$ \\
\hline $\begin{array}{l}\text { Giving feedback to } \\
\text { child/children }\end{array}$ & $\begin{array}{c}0 \\
(0)\end{array}$ & $\begin{array}{c}8 \\
(10 \%)\end{array}$ & $\begin{array}{c}23 \\
(28.8 \%)\end{array}$ & $\begin{array}{c}25 \\
(31.3 \%)\end{array}$ & $\begin{array}{c}24 \\
(30 \%)\end{array}$ \\
\hline
\end{tabular}

Between fifty-eight (58\%) and sixty-three percent (63\%) were supportive of learning-at-home activities. About two-thirds of the parents read to their child/children and helped them with homework and studying.

\section{Decision Making}

Table 6 shows the respondents' participation in decision making. The same pattern of responses were observed for decision making. The respondents were least involved in developing plans and programmes for the school (53\%). Other decision making activities showed a considerable number of involved parents, like participating in the school's counseling activities $(71.3 \%)$, being active in the parent-teacher association (65\%), having a say in selecting parent leaders (64\%), and deciding solutions for the school's conflicts (63\%).

Table 6

Albanian Parents' Involvement in Decision Making ( $\mathrm{N}=80)$

\begin{tabular}{|c|c|c|c|c|c|}
\hline \multirow{2}{*}{ Parenting Item } & \multicolumn{5}{|c|}{ Frequency } \\
\hline & Never & Rarely & Sometimes & Frequently & Always \\
\hline $\begin{array}{l}\text { Being active in PTA \& } \\
\text { PTO }\end{array}$ & $\begin{array}{c}0 \\
(0)\end{array}$ & $\begin{array}{c}6 \\
(7.5 \%)\end{array}$ & $\begin{array}{c}22 \\
(27.5 \%)\end{array}$ & $\begin{array}{c}26 \\
(32.5 \%)\end{array}$ & $\begin{array}{c}26 \\
(32.5 \%)\end{array}$ \\
\hline $\begin{array}{l}\text { Participating in the } \\
\text { school's counseling } \\
\text { activities }\end{array}$ & $\begin{array}{c}1 \\
(1.3)\end{array}$ & $\begin{array}{c}10 \\
(12.5 \%)\end{array}$ & $\begin{array}{c}12 \\
(15 \%)\end{array}$ & $\begin{array}{c}31 \\
(38.8 \%)\end{array}$ & $\begin{array}{c}26 \\
(32.5 \%)\end{array}$ \\
\hline $\begin{array}{l}\text { Taking part in selecting } \\
\text { parent leaders for } \\
\text { committees }\end{array}$ & $\begin{array}{c}1 \\
(1.3)\end{array}$ & $\begin{array}{c}13 \\
(16.3 \%)\end{array}$ & $\begin{array}{c}15 \\
(18.8 \%)\end{array}$ & $\begin{array}{c}29 \\
(36.3 \%)\end{array}$ & $\begin{array}{c}22 \\
(27.6 \%)\end{array}$ \\
\hline
\end{tabular}




\begin{tabular}{lccccc}
$\begin{array}{l}\text { Helping school decide } \\
\text { solutions to deal with } \\
\text { conflicts }\end{array}$ & 0 & 16 & 14 & 28 & 22 \\
& $(0)$ & $(20 \%)$ & $(28.0 \%)$ & $(35.0 \%)$ & $(27.5 \%)$ \\
$\begin{array}{l}\text { Developing plans and } \\
\text { programmes }\end{array}$ & 2 & 4 & 32 & 30 & 12 \\
\hline
\end{tabular}

\section{Collaborating with the Community}

Table 7 shows the respondents' collaboration with the community. Less involvement was reported in this aspect. Most parents were not or rarely involved in collaborating with the community in terms of helping other families (54\%), collaborating with businesses and industries (54\%), and organizing after-school programmes (56\%). Between 30 and 39\% reported some involvement in these activities with the community.

Table 7

Albanian Parents' Community Collaboration $(\mathrm{N}=80)$

\begin{tabular}{|c|c|c|c|c|c|}
\hline \multirow{2}{*}{ Parenting Item } & \multicolumn{5}{|c|}{ Frequency } \\
\hline & Never & Rarely & Sometimes & Frequently & Always \\
\hline $\begin{array}{l}\text { Helping other } \\
\text { families }\end{array}$ & $\begin{array}{l}14 \\
(17.5 \%)\end{array}$ & $\begin{array}{l}29 \\
(36.3 \%)\end{array}$ & $\begin{array}{l}28 \\
(35 \%)\end{array}$ & $\begin{array}{l}9 \\
(11.3 \%)\end{array}$ & $\begin{array}{l}0 \\
(0)\end{array}$ \\
\hline $\begin{array}{l}\text { Collaborating } \\
\text { with businesses } \\
\text { and industries }\end{array}$ & $\begin{array}{l}17 \\
(21.3 \%)\end{array}$ & $\begin{array}{l}26 \\
(32.5 \%)\end{array}$ & $\begin{array}{l}31 \\
(38.8 \%)\end{array}$ & $\begin{array}{l}6 \\
(7.5 \%)\end{array}$ & $\begin{array}{l}0 \\
(0)\end{array}$ \\
\hline $\begin{array}{l}\text { Organizing } \\
\text { afterschool } \\
\text { programmes }\end{array}$ & $\begin{array}{l}17 \\
(21.3 \%)\end{array}$ & $\begin{array}{l}28 \\
(35.0 \%)\end{array}$ & $\begin{array}{l}24 \\
(30 \%)\end{array}$ & $\begin{array}{l}11 \\
(13.8 \%)\end{array}$ & $\begin{array}{l}0 \\
(0)\end{array}$ \\
\hline
\end{tabular}

\section{Parental Involvement by Age Group}

A one-way ANOVA was run to compare the impact of age on the six categories of parental involvement. The respondents were divided into five age groups: (i) Group 1 (18-19 years); (ii) Group 2 (20-29 years); (iii) Group 3 (30-39 years); (iv) Group 4 (40-49 years); and (v) Group 5 (50 years and above). The results are summarized in Table 8.

Table 8

ANOVA Results on Parental Involvement Differences by Age Group

\begin{tabular}{lccccc}
\hline & Sum of Squares & Df & Mean of square & F & Sig \\
\hline Parenting & 121.867 & 4 & 30.467 & 1.911 & .117 \\
Communication* & 774.788 & 4 & 193.697 & 2.702 & .037 \\
Volunteering* & 3122.574 & 4 & 30.643 & 3.534 & .011 \\
Learning at home & 135.496 & 4 & 33.874 & .649 & .629 \\
Decision making & 601.713 & 4 & 150.428 & 2.188 & .078 \\
Collaborating with the community & 36.436 & 4 & 9.109 & 1.498 & .211 \\
\hline
\end{tabular}

Note: *Statistically significant difference at $p<0.05$ 
The results did not show statistically significant differences among the age groups in four of the six categories. The age groups did not differ significantly in terms of parenting at $p>.05$, learning at home $(p=.629)$, decision making $(p=.078)$, and collaborating with the community $(p=.211)$. Only two categories were found to significantly differ among the age groups, namely volunteering $(p=0.011)$ and communication $(p=.037)$.

A post hoc analysis using the Tukey test showed that the significant difference occurred between Group 2 (20 to 29 years of age) and Group 4 (40 to 49 years of age) parents at $p=$ 0.15. It was observed that Group 4 parents had a higher mean score on volunteering than Group 2. In terms of communication, differences were detected between Group 5 (50 years and more) and Group 2 (20-29 years) parents at $p=.035$. Parents in Group 5 (50 years and more) had a significantly higher mean score on communication than those in Group 2 (20 to 29 years of age).

\section{Parental Involvement by Marital Status}

The respondents were divided into five marital statuses, namely Group 1 (Married Parents); Group 2 (Divorced/Separated); Group 3 (Remarried Parents); Group 4 (Widowed Parents); and Group 5 (Never Married Parents). The ANOVA results are summarized in Table 9:

Table 9

ANOVA Results on Parental Involvement Differences by Marital Status

\begin{tabular}{lccccc}
\hline & Sum of Squares & Df & Mean of square & F & Sig \\
\hline & 495.671 & 4 & 123.918 & 11.309 & .000 \\
Parenting* & 619.302 & 4 & 154.825 & 2.099 & .089 \\
Communication & 237.728 & 4 & 59.432 & 8.329 & .000 \\
Volunteering * & 296.602 & 4 & 74.150 & 1.482 & .216 \\
Learning at home & 733.922 & 4 & 183.481 & 2.739 & .035 \\
Decision making* & 60.259 & 4 & 15.065 & 2.615 & .042 \\
Collaborating with the & & & & &
\end{tabular}

\section{Note: $*$ Statistically significant difference at $p<0.05$}

Significant differences were found in regard to four of the six types of parent involvement, namely parenting $(p=.001)$, volunteering $(p=.001)$, decision making $(p=$ $0.035)$, and collaborating with the community $(p=.042)$. The post hoc analyses using the Tukey test found significant differences between married and divorced or separated parents at $p=.001$, and between remarried and widowed parents at $p=.012$. Married parents had a higher mean score on parenting than divorced or separated counterparts. Significant differences also occurred between remarried and widowed parents at $p=.001$, where the remarried parent group exhibited a higher mean score than the other two groups. Group 5 parents (who never married) did not differ significantly from the other groups in terms of parenting.

In terms of volunteering, differences were detected between the divorced/separated and married groups at $p=.001$, and between the widowed and remarried parent groups at $p=$ .001 . Remarried parents had a higher mean score on volunteering than widowed parents at $p=.002$. The never-married parent group did not differ significantly from the rest of the groups. In terms of decision making, differences were detected between the divorced/separated parents and the never-married parents at $p=.033$. The latter group (the never-married parents) showed a higher mean score on decision making than other parents. In terms of collaborating with the community, the remarried group exhibited a higher mean score than the divorced/separated group, and this difference was statistically significant at $p=.032$. 


\section{Parental Involvement by Education Level}

The respondents were divided into 5 education groups, namely Group 1 (with less than a high school education), Group 2 (high school education), Group 3 (college education), Group 4 (bachelor's degree), and Group 5 (graduate degree). The ANOVA results are summarized in Table 10.

Table 10

ANOVA Results on Parental Involvement by Education Level

\begin{tabular}{lccccc}
\hline & Sum of Squares & Df & Mean of square & F & Sig \\
\hline Parenting* & 648.820 & 4 & 162.205 & 18.193 & .001 \\
Communication * & 1511.920 & 4 & 377.980 & 6.110 & .001 \\
Volunteering * & 445.386 & 4 & 111.347 & 25.499 & .001 \\
Learning at home & 435.410 & 4 & 108.852 & 2.259 & .071 \\
Decision making & 385.407 & 4 & 96.352 & 1.345 & .261 \\
Collaborating with the community & 201.973 & 4 & 50.493 & 13.040 & .001 \\
$*$ & & & & & \\
\hline
\end{tabular}

Note: *Statistically significant difference at $p<0.05$

The results did not show statistically significant differences in two of the six categories, namely learning at home at $p>.05$ and decision making at $p=.261$. The remaining four parent involvement aspects were significantly different, namely parenting, communication, volunteering and collaborating with the community, all at $p=.001$. The post hoc analyses with the Tukey test discovered significant difference to occur among Group 1 (less than high school education), Group 3 (college education), Group 4 (bachelor's degree), and Group 5 (graduate degree) where Group 5 parents had the highest mean score on parenting than their counterparts in all other groups. Group 2 parents (with a high school diploma) did not differ significantly from the rest of the groups.

In terms of communication, statistically significant differences were detected between Group 1 parents (less than a high school education) and their Group3 college-educated counterparts at $p=.001$, as well as with parents with a graduate degree (Group 5) at $p=.003$. It was observed that parents with a graduate degree had higher mean score on communicating with the school than did their counterparts in other groups. However, Group 2 and Group 4 parents did not differ significantly from the other groups in this aspect.

In terms of volunteering, differences were detected between parents with less than a high school diploma (Group1) and those with a college education (Group3) at $p=.001$ as well as with parents with a bachelor's degree (Group 4) at $p=.003$ and a graduate degree (Group 5) at $p=.001$. It appeared that parents with a graduate degree had a higher mean than the others, while parents with a high school diploma did not differ significantly from the rest of the groups.

In terms of collaborating with the community, differences were detected between parents with less than a high school education and those in three other groups, namely college educated parents, and parents with a bachelor's and graduate degree, all at $p=.001$. In this case, parents with a bachelor's degree had a higher mean score than the rest. High school educated parents, however, did not differ significantly from the rest of the groups in this aspect of parent involvement. 


\section{Parental Involvement by Income Level}

The next run of ANOVAS compared parental involvement by income level (measured in the Albanian currency leke). The respondents were divided into five income groups, namely Group 1(0-10,000 leke); Group 2 (10,000-20,000 leke); Group 3 (20,000-30,000 leke); Group 4 (30,000-40,000); and Group 5 (50,000 and more leke). The results are summarized in Table 11.

Table 11

ANOVA Results on Parental Involvement by Income Level

\begin{tabular}{lccccc}
\hline & $\begin{array}{c}\text { Sum of } \\
\text { Squares }\end{array}$ & Df & Mean of square & F & Sig \\
\hline Parenting* & 674.442 & 4 & 168.610 & 19.665 & .001 \\
Communication & 471.344 & 4 & 117.836 & 1.556 & .195 \\
Volunteering* & 371.088 & 4 & 92.772 & 17.317 & .001 \\
Learning at home & 346.850 & 4 & 86.712 & 1.756 & .147 \\
Decision making* & 939.678 & 4 & 234.920 & 3.657 & .009 \\
Collaborating with the community & 102.267 & 4 & 25.567 & 4.915 & .001 \\
$*$ & & & & & \\
\hline
\end{tabular}

Note: *Statistically significant difference at $p<0.05$

The results showed statistically significant differences in four categories. The income groups did not differ significantly in only two aspects, namely communication $(p=.195)$ and learning at home $(p=.147)$. The post hoc analyses using the Tukey test discovered that Group 5 parents with a monthly income of 50,000 leke or more had a higher mean score than parents in other groups. Another discovery was that Group 4 parents (with an income bracket of 30,000 to 40,000 leke) did not differ significantly from the rest of the groups.

Group 5 parents were significantly higher in volunteering, With respect to collaborating with the community, differences were detected between Group 1 (0-10,000 leke) and Group 2 $(10,000-20,000$ leke) parents at $p=.001$. Significant differences were also noted among Group 3 (20,000-30,000 leke), Group 4 (30,000-40,000 leke), and Group 5 (50,000 or more leke) parents. It was observed that Group 2 parents had a higher mean score on collaborating with the community than parents in other groups, while Group 5 parents did not differ from Group 1 (0-10,000 leke) and Group 2 (10,000-20,000 leke) parents in this component.

\section{Relationship Between Parenting and Communication}

The results presented in this part address the third research question, "What is the relationship between parenting and communication, i.e. the two categories of parental involvement examined in the study? A Pearson product-moment correlation test was run on the two summated scores that represented parenting and communication. The results are shown in Table 12.

Table 12

Correlation between Parenting and Communication

\begin{tabular}{llcl}
\hline & & Parenting & Communication \\
\hline Parenting & Pearson correlation & 1 & $.479^{* *}$ \\
& Sig. (2-tailed) & 80 & .000 \\
& $\mathrm{~N}$ & 80 & 80 \\
\hline Communication & Pearson correlation & $.479^{* *}$ & 1 \\
& Sig. (2-tailed) & .000 & \\
& $\mathrm{~N}$ & 80 & 80 \\
\hline
\end{tabular}

**. Correlation is significant at the 0.01 level (2-tailed). 
The results indicated a significant relationship between the two components. The evidence allowed the researcher to conclude that there was a significant moderate relationship between parenting $(\mathrm{M}=18.86, \mathrm{SD}=4.08)$ and communication $(\mathrm{M}=28.05, \mathrm{SD}=8.82)$ at $r(80)=.479$, $p=.001$. In other words, the results indicate that parents who were highly involved in parenting were also highly involved in communication activities about their children's schooling.

\section{DISCUSSION AND CONCLUSION}

The findings can be summarized as follows. First, Albanian parents on average based on the sample, were mostly involved in the education and schooling of their children in four of Epstein's categories. In descending order, they mostly took active part in the aspects of volunteering (64.2\%), that is helping out the school with various events and activities, parenting (63\%), that is keeping a check on their children, decision making (63\%) and learning at home $(61 \%)$. The parents reported helping their children study and making sure they completed their homework. Less involvement was reported in the areas of communication $(48.6 \%)$ and collaborating with the community (11\%).

Second, parental involvement tends to vary by demographic factors like age and marital status. Older parents between the ages of 40 to 49 volunteered more frequently than did younger parents of between 20 and 29. Parents aged 40 to 49 also tend to be more committed to volunteering in and attending school-related events than parents of other age groups. The finding may suggest that parents of this age group are perhaps more interested in school involvement than their younger or older counterparts.

Third, marital status had an influence on involvement where married parents exhibited a higher mean score on parenting than widowed or unmarried parents. Married parents also tend to volunteer and collaborated significantly more with the community than the unmarried or divorced/separated parent groups. Fourth, education level caused some variation in parental involvement where highly educated parents (those with graduate degrees) had the highest report of parenting, volunteering, and collaborating with the community. Parents with postgraduate degrees also reported more frequent communication with the school than the other parent groups. This group also had the highest income level and surpassed all others in terms of parenting and volunteering.

To conclude, parents who were highly educated, more advanced in age, and high income earners tend to show greater involvement. They attended school events. and communicated and met with the teachers more frequently. In Albania, awareness about the importance of education has increased among parents during the last 10 years. Therefore, the more educated the parents, the more likely they are going to attach an importance to parental involvement in schooling.

The findings of this study revealed how cooperation between the home and school is necessary in Albania, and elsewhere. Significant differences were found in Epstein's six parent involvement components as a function of income levels, educational level, age, and marital status. Many respondents agreed that educated parents affect student achievement in positive ways because these groups of people tend to have better communication with teachers and principals.

This study found that educated parents tend to be more frequently involved in the parenting, communication, and volunteering processes in their children's schooling. These 
processes and activities enable educated parents to understand education and schools better. This understanding in turn helps the schools to understand the home. Educated parents have the ability to provide and develop home conditions or environments that support learning. In contrast, parents and families with difficulties or parents with personal or family issues tend to be hampered in their involvement in the schooling process. Having a low income may cause certain families to experience issues and difficulties, in addition to other factors. In general, the respondents of the study agreed that parent involvement is definitely a significant factor for students' academic achievement, but they still believed that schools also have a huge responsibility towards effective schooling.

\section{LIMITATIONS OF THE STUDY}

The study had several limitations. First and foremost, the sample size of 80 parents was small and may not be an adequate representation of the parent population under study. As such, the results may not provide an adequate picture of the prevalence of parental involvement in the selected Albanian school. In addition, the fact that the sample was taken from only one school in Fushe Kruje may also have compromised the results. Had the study been conducted in more parts of Albania, it would have given a better picture of the prevalence of parent involvement in the country. Therefore, the results of this study cannot be generalized to parents from other parts of Albania. Additionally, the respondents' participation was voluntary and based on their willingness to provide the needed information. As such, the results are limited to those parents who are willing to provide the information and those that demonstrate the same positive attitude towards being part of the research.

\section{RECOMMENDATIONS FOR FURTHER RESEARCH}

Schools should build programmes and activities for parents to involve in education, and establish friendly relationships among parents, staff and teachers. These programmes and activities will increase the quality time parents and children spend together. In Fushe Kruje, there are many families who come from cities and villages across the country, and therefore, it is necessary to help students to make various adjustments as needed.

Parents must be made more aware about their role in their children's education, and the effects of having a quality family environment and atmosphere on the children's achievements. They should make efforts to create a positive relationship with teachers based on respect and mutual trust, and furnish teachers with detailed information about their children's academic achievements.

Future research should study the factors that affect the good relations between teachers and parents. Schools should have knowledge of ways to organize parental involvement inside and outside the school, as well as a sufficient understanding of the philosophy behind familyschool collaboration where parents are the main partners of the school and have rights and responsibilities. Further research needs to be done on the everyday life contexts of the family and in particular, parent-child relationships. Researchers should also study the quality of the tasks provided by parents at home and the types of task that are more productive for educating children. 


\section{REFERENCES}

Al Haris, M., \& Jarrar, A. (2014). Parents, teachers and school administration degree of acceptance for the parental kindergarten participation program and its impact on the Educational Learning process - Jordanian Sample. Journal of Education and Practice, 5(9), 169-178.

Anderson, K., \& Minke, K. (2007). Parent involvement in education toward understanding of parents' decision making. The Journal of Educational Research,

100(5), 311-323.

Berger, E.H. (1991). Parent involvement: Yesterday and today. The Elementary School Journal, 91, 209-219.

Barnard, W. M. (2004). Parent involvement in elementary school and educational attainment. Children and Youth Services Review, 26(1), 39-62.

Baroody, A., \& Dobbs-Oates, J. (2009). Child and parent characteristics, parental expectation, and child behaviours related to preschool children's interest in literacy .Early Child Development and Care, 181(3), 345-359.

Bloom. (1997).parenting our school .Canada: Little, Brown and Company. Cooper, C. E. (2010). Family poverty, school-based parental involvement, and policy- focused protective factors in kindergarten. Early Childhood Research Quarterly, 25(4), 480492.

Christenson, S. L., \& Hurley, C. M. (1997). Parents' and school psychologists' perspectives on parent involvement activities. School Psychology Review, 26(1), 111-130

Chuan, C. L. (2007). Sample Size Estimation Using Krejcie and Morgan and Cohen Statistical Power Analysis :A Comparison. Jurnal Penyelidikan IPBL, 7, 78-86.

Deplanty , J., Coulter,Kern , R., \& Duchane , k. (2007). Perceptions of parent involvement in academic achievement. The Journal of Educational Research, 100(6), 361-368.

Edwards, \& Rosalind. (2002). children, home, and school: Regulation, autonomy for connection. London: Routedge Falmer.

Epstein, J. (1995). School/family/community partnerships: Caring for the children we share. Phi Delta Kappan, 76, 701-712.

Epstein, J. (2003). Creating school, family, and community partnerships. In A.C. Ornstein, L.S. Behar-Horenstein, \& E.F. Pajak (Eds.), Contemporary+issues+in+curriculum+(3rd ed.) (pp. 354-373). Boston, MA: Allyn and Bacon.

Epstein, J., Sanders, M., Sheldon, S., Simon, B., Salinas, K., Jansorn, N., et al. (2009). School, Family, and community partnerships: Your handbook for action. Thousand Oaks, CA: Corwin. 
Fink, A. (2003). How to sample in surveys. Thousand Oaks, CA: Sage. Flaxman, E., \& Inger, M. (1991). Parents and schooling in the 1990s. ERIC Review, 1(3), 2-6.

McMillan, J., \& Schumacher, S. (2006). Research in education: Evidence based inquiry. Boston, MA: Allyn and Bacon.

Metani, I. (2003). Transforming education : the Albanian experience . Nova Science Publishers, Inc.

Mertler, C. A., \& Vannaatta, R. A. (2010). Advanced and multivariate statistical methods Practical application and interpretation (4th ed.). Glendale, CA:Pyrczak Publishing.

Hashmi, A., \& Akhter, M. (2013). Assessing the Parental Involvement in Schooling of Children in Public Private Schools, and its Impact on their Achievement at Elementary Level. Journal of Education Research, 16(1), 27-38.

Hara, S. R. (1998). Parent involvement: The key to improved student achievement. School Community Journal, 8(2), 9-19.

Henderson, A.T. \& Mapp, K.L. (2002). A new wave of evidence: The impact of school, family And community connections on student achievement. Austin, TX:Southwest Educational Development Laboratory, National Centre for Family and Community Connections with Schools. Retrieved http://www.sedl.org/connections/resources/evidence.pdf

Hill, N. E., Castellino, D. R., Lansford, J. E., Nowlin, P., Dodge, K. A., Bates, J. E.(2004).Parent academic involvement as related to school behavior, achievement, and aspirations : Demographic variations across adolescence. Child Development,75(5), 1491-1509.

Jordan, C., Orozco, E., \& Averett, A. (2002). Emerging issues in school, family, and community connections: Annual synthesis 2001. Austin, TX: Southwest Educational Development Library.

Lee, J.-S., \& Bowen, N. (2006). Parental Involvemnt, Cultural Capital and the Achievement Gap Among Elementary School Children. American Educational Research Jonural, 43(2), 193-218.

Litwin, M. (2003). How to assess and interpret survey psychometrics. Thousand Oaks, CA: Sage.

Lunenburg, F. C. \& Irby, B. J. (2002). Parent involvement: A key to student achievement. Paper Presented at the Annual Meeting of the National Council of professors of Education Administration, Burlington, VT, August 5-10, 2002 [ERIC Document Reproduction Service No. ED 468558].

Tam, V., \& Chan , R. (2009). Parental Involvement in Primary Children's Homework in Hong Kong. The School Community Journal, 19(2), 81-100.

Trusty, J. (1999). Effects of eighth-grade parental involvement on late adolescents' educational expectations. Journal of Research and Development in Education, 32, 224-233. 
Reynolds, A. J. (1991). Comparing measures of parental involvement and their effects on academic achievement. Early Childhood Research Quarterly, 7(3), 441-462.

Ringenberg, M., Funk, V., Mullen, K.,Wilford, A.,\& Kramer, J. (2005). The test-retest reliability of the parent and school survey (PASS). School Community Journal, 15(2), 121-134. (ERIC Document Reproduction Service No. EJ794812) Retrieved March 26, 2015, from ERIC database.

Sheldon, S. (2003). Linking school-family-community partnerships in urban elementary schools to student achievement. The Urban Review, 35, 149-165.

Simon, M.K., \& Goes, K. (2013). Dissertation and scholarly research: recipes for success. Seattle, WA: Dissertation Success LLC.

Swap, S.M. (1993). Developing home-school partnerships: From concepts to practice. New York: Teachers College Press.

Vellymalay, S. K. (2012). Parental Involvement at Home: Analyzing the Influence of Parents 'Socioeconomic Status. Studies in Sociology of Science, 3(1), 1-6. 